\title{
Natural Ventilation Performance for Schools During a Pandemic and the Post-Pandemic COVID 19
}

\section{Dyah Hendrawati ${ }^{1}$}

${ }^{1}$ Architecture Department, Faculty of Civil Engineering And Planning, Universitas Islam Indonesia, Yogyakarta

\author{
Article History \\ Received : 25 August 2021 \\ Accepted : 14 October 2021 \\ Published : 30 October 2021
}

\begin{abstract}
Natural ventilation is applied to most educational buildings in Indonesia. Natural ventilation is one of the strategies to achieve the physical comfort of residents and an effort to save energy. During a pandemic, natural ventilation requires because it is expected to make the air circulation in the room. The presence of good air circulation will make the spread of the virus can be avoided. One indicator of the success of space for good and healthy air circulation is the achievement of Air Change per Hours (ACH) values according to standards. The study aims to find out and identify the performance of natural ventilation as an element that determines indoor air circulation against the spread of the covid 19 viruses, comfortable air velocity in a room and user capacity. The study used simulation methods to determine the value of $\mathrm{ACH}$ and air velocity. The research main goal was to look at the possibility of reopening schools as safely and quickly as possible. The results showed that the school buildings studied could be used for Pandemic and postpandemic times, indicated by $\mathrm{ACH}$ grades $>8$ and air velocity in room $0.2-0.8 \mathrm{~m} / \mathrm{s}$. The building has an opening area of approximately $30 \%$ with an opening type that is able $45 \%$ wind flow. With the simulation obtained, to achieve health and comfort standards with $50 \%$ users, with certain air velocity conditions, the minimum opening area is $20 \%$ with $45 \%$ aperture type and $90 \%$ type.
\end{abstract}

Keywords: $\mathrm{ACH}$; natural ventilation; performance; window types

\section{Introduction}

Based on statistical data compiled from the official WHO website related to COVID-19, the trend of cases that occur in Indonesia tends to increase again after briefly falling in April 2021, with the highest issues in the fourth week of July 2021, with the positive rate of COVID-19 cases still high, because it is still above $10 \%$ (https://covid19.who.int).

It should be a concern to remain and comply with established health protocols (prokes), as the COVID-19 Pandemic is not over yet. The main priority is to reduce transmission because infection prevention is the best approach to prevent transmission. Sars-CoV-2 transmission

Correspondence: Dyah Hendrawati

Architecture Department, Faculty of Civil Engineering And Planning, Universitas Islam Indonesia, Yogyakarta E-mail: dhendrawati@uii.ac.id can occur through contact with infected people, through infected secretions such as saliva and respiratory secretions or droplets of their breathing released by an infected person (Ghinai et al. I, 2020, Chan et al. I, 2020).

Direct transmission of the virus through Direct transmission of viruses can be through tiny micro-air or airborne droplets and particles (Domingo et al., 2020). These can produce the aerosols in two ways: evaporation through breathing respiratory droplets produces microscopic aerosols, and speech produces exhaled aerosols. Therefore, vulnerable people can inhale aerosols and risk infection if the aerosol contains a quantity of the virus. (Hadei et al., 2020)

Preventive and mitigation efforts need to be optimized and can be observed from flashbacks of the COVID-19 spread process so far. Based on the cases, there are spread clusters from 
Natural Ventilation Performance for schools during a Pandemic and the Post-Pandemic COVID 19 Dyah Hendrawati
COVID-19, such as office clusters, family clusters, settlement clusters. This cluster is also called a cluster in a building (indoor). Cluster is quite understandable because $90 \%$ of human time is spent on activities in buildings. School clusters are very likely to occur if learning begins face-to-face/offline.

Several studies show that the effectiveness of online learning is low in primary and higher education (Mahdy, 2020; Nambiar, 2020). In Indonesia, research that the effectiveness of online learning during the Covid-19 Pandemic is $39.6 \%$, meaning it is in a low category (Lubis, 2020, Astuti 2021). The classroom is one of the significant factors to note if face-to-face learning is about to begin. In addition to classrooms for schools with boarding school systems need to be also considered for the bedroom. Direct transmission of the virus through airborne small airborne micro-droplets and particles (aerosols) (Domingo et al., 2020) In a limited space of transmission of coronavirus 2019 (COVID 19) has a possibility of contracting 18.7 times greater than the open environment. (Nishiura et al., 2020).

In a room with inadequate air, conditioning airflow resulted in the infection, ten people from three families had eaten at the same airconditioned restaurant X in Guangzhou, China. (Lu et al., 2020). Research shows the role of natural ventilation in preventing the spread of viruses during a pandemic. Natural ventilation has helped to contain the spread of SARS (Severe acute respiratory Syndrome) in 2009 cases of the reach of flu in Americain 2009.

\section{Literature Review}

\section{Natural Ventilation}

Wind from natural vents that move inside the building through openings, the effect of temperature or pressure differences. Natural ventilation takes advantage of the high air pressure on one side of the building (inlet) so that the wind will come from that direction towards the other side of the building with low pressure (outlet). So that air can enter the building is not trapped and only moves from one corner of the room to another. Natural ventilation occurs in openings such as doors, windows, and open spaces in buildings. Cross ventilation as a method of channelling air can flow air from one side of the building to another. That way, the air circulation in the building becomes healthy because the air in the room is constantly changing, and the user is always breathing new air.

Design-based natural ventilation potential has been discussed in several papers. Natural ventilation can do the initial design of natural ventilation can be done in a way based on the target rate of air change in space (Hiyama \& Glicksman 2015). Good ventilation design must be based on an understanding of airflow patterns and their consequences for surrounding buildings to produce a room with clean air circulation throughout the room, which relates to the location of the windows and the character of the wind (Geetha \& Velraj, 2012). Poor ventilation and air circulation systems are the factors causing Sick Building Syndrome, which is caused by no process of air circulation inside or outside the room (Camelia, 2011).

\section{Location, Type and Dimension of Openings}

Natural ventilation has a significant effect on air quality. The location and type of ventilation will affect the exchange of air, clean air can enter the space, and dirty air does not accumulate in the room.

Ventilation systems and the presence of humans in the room affect the present company of colonies of airborne microbes. In addition, some confounding variables that affect the presence of airborne microorganisms in order of magnitude of influence on the number of microbial colonies of air are temperature, humidity and light intensity. (Rachmatantri et al., 2015)

Figure 1. Effect of opening types on wind flow Source: Bangunan Tropis, Lippsmeier

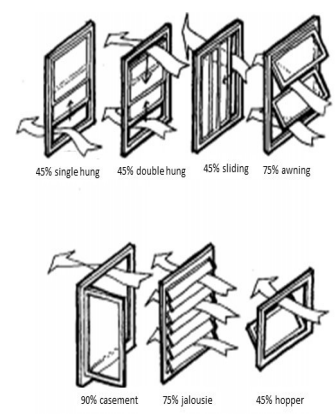

Types of openings and optimization of cross ventilation also influence air quality in space. 
Less than optimal types of openings/windows used and lack of cross-ventilation can reduce the volume of clean air entering the area. Minimal cross ventilation can also result in a lack of air changes from indoors to the outdoors or vice versa, thus allowing the collection of dirty air from the outdoor environment brought into the room. Therefore, it can conclude that natural ventilation has a significant influence on air quality related to the phenomenon of sick building syndrome. To get good air quality and reduce the risk of sick building syndrome, always try to keep movement or air circulation (cross ventilation). Room settings need to consider the location of good ventilation and the selection of the appropriate type of ventilation to reduce the energy load by utilizing maximum natural ventilation. Thus the exchange of air in space becomes more effective.

Figure 2. Effect of opening and overhang on wind flow Source: Heating, Cooling, Lighting, 2015

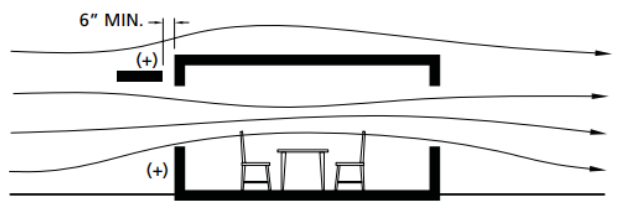

Rules on natural ventilation in Indonesia already exist, Standard Nasional Indonesia (SNI) 03-6572 the year 2001 about Procedures for Designing Ventilation and Air Conditioning Systems in Buildings. The SNI regulates the ratio of openings to the floor area of at least $5 \%$ but has not set the location of opening/ windows. The research results on the distribution of classroom air flow recommend the location and the opening ratio of $21.6 \%$ of the floor area with inlet details of $14.5 \%$ and outlets $7.1 \%$ facing positions (Latif et al. 2016).

\section{Air Changes per Hours (ACH)}

$\mathrm{ACH}$ is the number of air changes per hour, the amount of air change that occurs within an hour in a room ( Lechner, 2015).

The unit used to measure airflow for health and comfort is the change of air per hour (air change per hour-ACH), the number of air changes that occur within an hour in space. To minimize the risk of COVID-19 transmission in classrooms, one should avoid spending long periods in an area with many people and be safer in a room with large volumes. dan tingkat ventilasi minimum 3-4 ACH ( Bazant et al., 2021).

Air quality in space also is determined from the standard airflow rate in the room. Considering ventilation creates an urgency to assess the health building in the mid of the COVID-19 Pandemic, we can evaluate the building based on several published standards. Indonesian National Standards set the minimum opening for ventilation to be $5 \%$ of the room's total area (SNI Indonesia 6572-2001). Meanwhile, Minister of Health of the Republic of Indonesia Number 829 / MENKES / SK / VII / 1999 states that permanent natural ventilation or ventilation is at least $10 \%$ of the floor area. Regarding the $\mathrm{ACH}$ (Air Changes per Hour), ASHRAE recommends school buildings have $5-6 \mathrm{ACH}$ (not include lecture hall). Meanwhile, while dealing with the viruses, the recommendation for the ventilation rate is up to $8 \mathrm{ACH}$.

Rooms with good ventilation will minimize people exposure to viral infections, while rooms with poor ventilation allow the virus to rise significantly. The importance of adequate ventilation to supply clean outdoor air in public spaces to slow the spread of the virus through the air. In particular, natural ventilation has been widely suggested and successfully implemented in handling various epidemic diseases historically and can be an effective solution in preventing viral spread where costly mechanical ventilation systems are not installed. (Zhai, 2020). ASHRAE, 2000 has stated a potential danger of indoor air and recommended appropriate ventilation control measures. Shared spaces, such as malls, cafes, offices, conference rooms, schools, libraries, restaurants, elevators, and public transportation, which are public facilities, can use natural ventilation, considering the area of space, opening area and savings if using mechanical ventilation. Room in the hospital for better airflow rate is expected to add mechanical ventilation and natural ventilation. Natural ventilation in buildings allows for the spread of infection through the air. The results showed that the chance of infection is below $1 \%$ when studying in class for 2 hours if not using a mask, at least air change velocity is 7 $\mathrm{ACH}$ and if using mask minimal $2 \mathrm{ACH}$. (Dai \& Zhao, 2020).

In the summer in Korea, ventilation rate measurements are taken according to window 
Natural Ventilation Performance for schools during a Pandemic and the Post-Pandemic COVID 19 Dyah Hendrawati

opening ratios of 15,30 , and $100 \%$ under cross ventilation at 6.51, 11.20, and $22.43 \mathrm{ACH}$, respectively (Park et al., 2021).

In the summer in Korea, ventilation rate measurements are taken according to window opening ratios of 15,30 , and $100 \%$ under cross ventilation at 6.51, 11.20, and $22.43 \mathrm{ACH}$, respectively (Park et al., 2021).

To calculate air exchange per hour $(\mathrm{ACH})$ in a room/building can be using this formula:

$$
\mathrm{ACH}=(\mathrm{Q} / \mathrm{V}) \times 3600 \text {. }
$$

Where $Q$ is the level of natural ventilation $\left(\mathrm{m}^{3} / \mathrm{s}\right)$, and $V$ is the volume of the room $\left(\mathrm{m}^{3}\right)$.

The level of natural ventilation (Q) itself is obtained using the formula:

$$
\mathrm{Q}=0.025 \times \mathrm{A} \times \mathrm{v} \text {. }
$$

Where, $A$ is the area of the opening $\left(m^{2}\right), v$ is the wind speed at the opening $(\mathrm{m} / \mathrm{s})$, and 0.025 is the multiplier.

Air velocity dramatically affects the comfort of the room. The effect on comfort if ar velocity $0,05 \mathrm{~m} / \mathrm{s}$ is stagnant air, slightly and uncomfortable. Air velocity $0,2-0,8 \mathrm{~m} / \mathrm{s}$ the impact on comfort are comfort, and $1 \mathrm{~m} / \mathrm{s}$ is for air-conditioned space and good air velocity for natural ventilation in a hot and dry climate (Lechner, 2015).

\section{Ventilation Rate and Population Density}

At the time of the Pandemic, it expected that users' capacity density is recommended only $50 \%$ of standard conditions to maintain distance for health protocols. In-Classroom Safety Guidelines in the COVID-19 Pandemic Period for schools already regulate population density for classes.

Table 1. Safety Guidelines in Classrooms in the COVID-19 Pandemic for schools

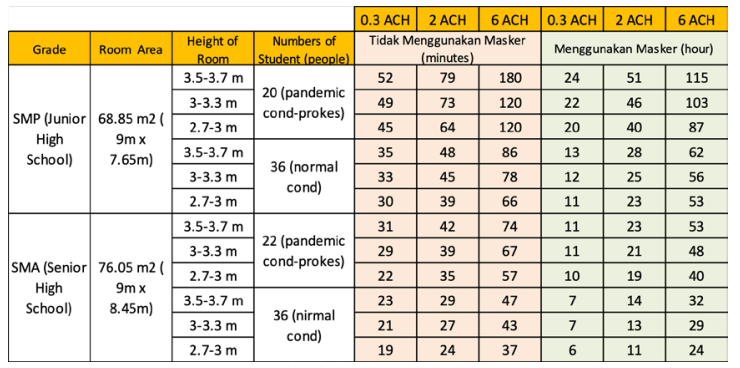

Source:http://web.mit.edu/bazant/www/COVID-19/

\section{Methodology}

This research uses quantitative methods by modeling objects and simulations with the help of computer software. The use of simulation methods is chosen to avoid the difficulty of direct research on real objects. This study used the finished building, namely SMPIT (Junior High School) Salman Al Farisi Boarding School, Sleman, Yogyakarta. The rooms to be studied are classrooms and dormitories. The building has the longest orientation west-east. The simulation method is used in experiments using computer software to produce predictions without conducting experiments directly. This method uses a replica (model) in a real-world context, which is controlled (manipulated) to study the interaction between the model's manipulated factors. In this case, the interaction between the building model and the simulated object location weather data.

The research was conducted by calculating the $\mathrm{ACH}$ value in the room and looking at the behavior and wind speed in the room using Solidworks Flow Simulation software.

Describes all methods used in the research; It is a comparison or narrative for multiple case study works or research projects over a long period of time. Research can also be experimental work. The research method should consist of all the steps until it finds results from the research objectives.

Independent variables used in research are window dimensions and window types. Fixed variables are space area, window position, wind speed.

\section{Result and Discussion}

During pandemics and post-pandemic, healthqualified schoolrooms become very important. If the school is going to carry out offline learning, not only is $\mathrm{ACH}$ achieved to standards, but space should also be convenient for activities related to wind speed in space. Should also consider space capacity about the minimum distance for health protocols. Here are the data, simulations and analyses conducted on this study. 


\section{$\mathrm{ACH}$, opening area and types of opening}

The room studied is a dormitory room, which is a bedroom. Space dimensions are $10 \mathrm{~m} \times 30 \mathrm{~m}$, with a $45 \%$ wind flow in hopper opening type and an outdoor air velocity of $1.8 \mathrm{~m} / \mathrm{s}$.

Figure 3: Dormitory- $\mathrm{ACH}$, opening area and types of opening

Source: Researchers, 2021

$\mathrm{ACH}$ in The Dormitory

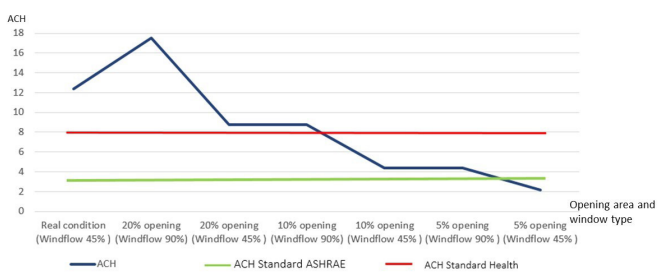

Existing conditions in dormitories indicate that the room is eligible for use during a pandemic or post-pandemic times without the help of mechanical ventilation, with an $\mathrm{ACH}$ value of 12.39.

Rooms with a $5 \%$ opening area with $45 \%$ wind flow opening type have ACH below ASHRAE standards and health standards. The most optimal for pandemic and post-pandemic conditions is an opening with an area of $20 \%$ with a wind flow opening type of $45 \%$ or an opening area of $10 \%$ with a wind flow of $90 \%$.

The classroom has $7.5 \mathrm{~m} \times 6 \mathrm{~mm}$ with a $45 \%$ wind flow in hopper opening type and an outdoor air velocity of $1.2 \mathrm{~m} / \mathrm{s}$.

Figure 4: Classroom - $\mathrm{ACH}$, opening area and types of opening

Source: Researchers, 2021

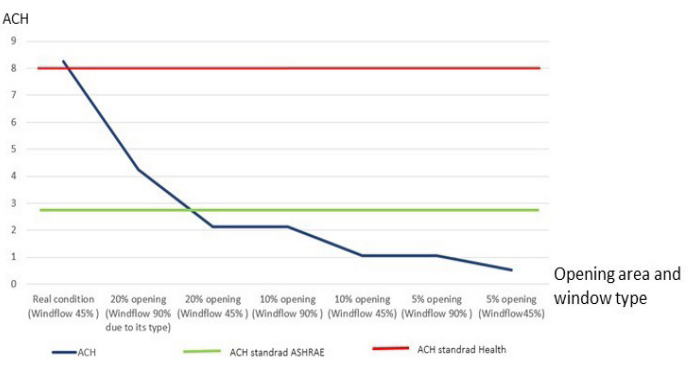

Classrooms with an outdoor air velocity of $1.05 \mathrm{~m} / \mathrm{s}$ for existing conditions indicate that the room is eligible for use during Pandemic or post-pandemic times without the help of mechanical ventilation. Calculations show the most optimal for Pandemic and post-pandemic conditions is an opening with an area of $20 \%$ with a wind flow opening type with a wind flow of $90 \%$.

Opening Area, Opening Types and Air Velocity Wind speeds in dormitory rooms that are still within comfortable limits for tropical countries are $0.2-0.8 \mathrm{~m} / \mathrm{s}$. The simulation showed that the wind speed in the dormitory room is still within comfort limits. There is no air velocity in the room when opening $5 \%$ with $45 \%$ aperture type so that the space is un comfort.

Figure 5: Dormitory-Air velocity and types of opening Source: Researchers, 2021

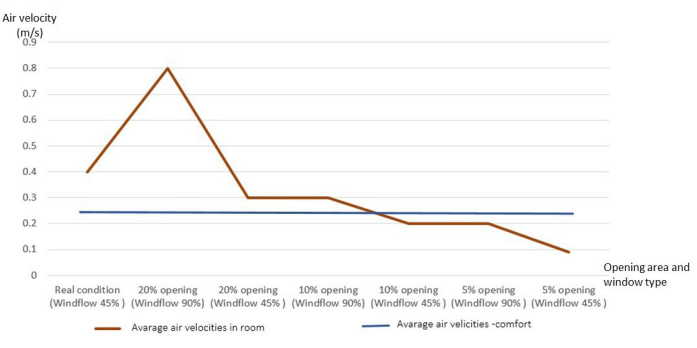

Figure 6: Dormitory-Air velocity Existing

Source: Researchers, 2021

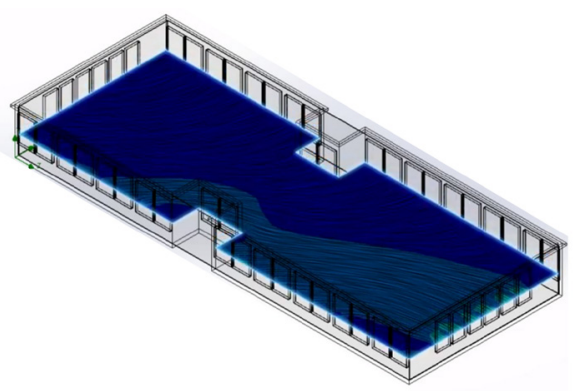

Figure 7: Dormitory-Air velocity $20 \%$ opening area and $45 \%$ wind flow

Source: Researchers, 2021

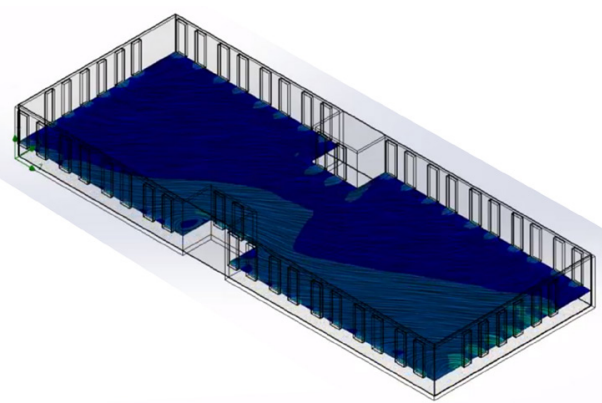

Air velocity in existing classrooms is comfortable. The simulation showed that the air velocity is low in space with an opening area of $20 \%$ with a type $90 \%$ wind flow opening. 
Natural Ventilation Performance for schools during a Pandemic and the Post-Pandemic COVID 19 Dyah Hendrawati

60

Figure 8: Classroom-Air velocity

Source: Researchers, 2021

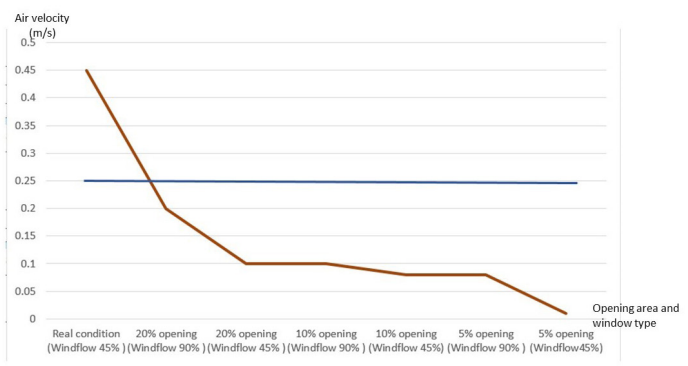

Figure 9: Classroom-Air velocity Existing Source: Researchers, 2021

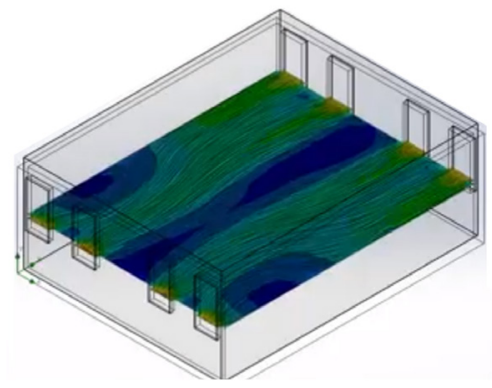

Figure 10: Classroom -Air velocity $20 \%$ opening area and $45 \%$ wind flow

Source: Researchers, 2021

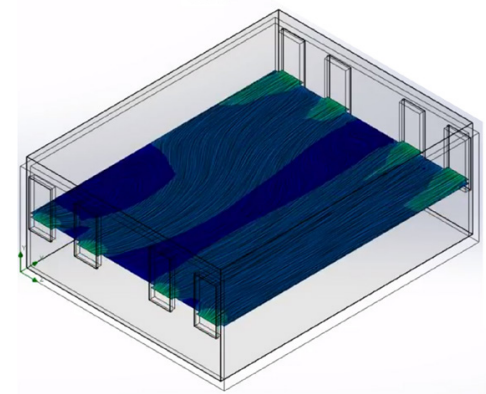

\section{$\mathrm{ACH}$ and Accupants Density}

During the Pandemic, there was a standard health protocol for minimal distance. It expects that with reduced space density, the potential for transmission also decreases.

Figure 11: Dormitory-Accupants density Source: Researchers, 2021

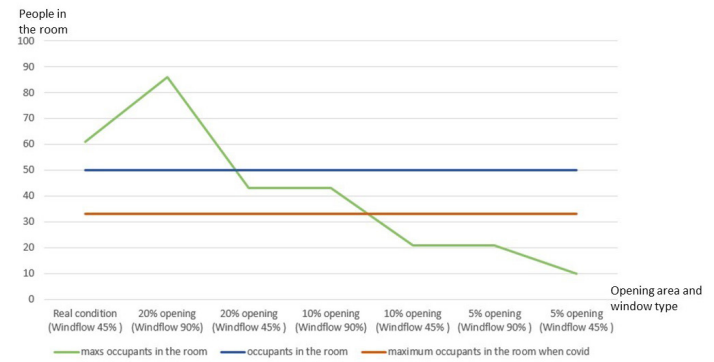

In dormitories, the condition of exiting, if you look at the need for air to breathe, is still within safe limits. In pandemic conditions, when the user is $50 \%$, the need for air circulation is still comfortable and healthy.

Figure 12:Classroom-Accupants density Source: Researchers, 2021

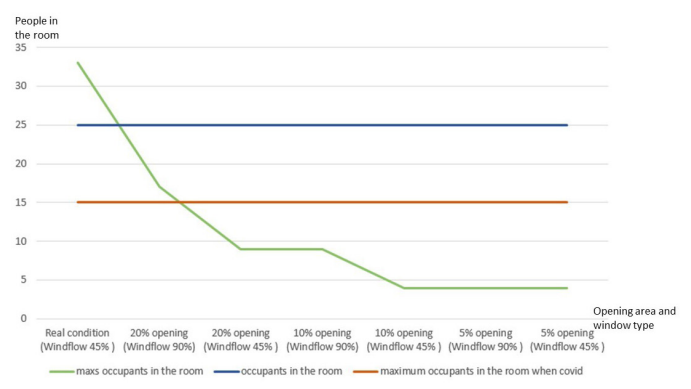

In classrooms, the condition of exiting, if you look at the need for air to breathe, is still within safe limits. In pandemic conditions, when the user is $50 \%$, the need for air circulation is still comfortable and healthy.

Research by taking measurements on the ground and then conducting simulations for the area of openings, window type and air velocity in school buildings, whether it meets the standards for use and overcomes pandemic and post-pandemic COVID-19. The results of this study are as follows:

(1) Existing dormitories and classrooms can be used during a pandemic and post-pandemic times in a healthy and comfortable manner, with $\mathrm{ACH}$ above 8 and air velocity in the room between $0.2-0.8 \mathrm{~m} / \mathrm{s}$, with a user capacity of $50-100 \%$.

(2) For dormitory is still healthy and comfortable in pandemic and post-pandemic, if the opening area is $20 \%$ with the type of opening $45 \%$ wind flow. $\mathrm{ACH}>8$ with air velocity $0,3 \mathrm{~m} / \mathrm{s}$ with a user capacity of $50 \%$.

(3) For classroom is still healthy and comfortable in pandemic and post-pandemic, if the opening area is $20 \%$ with the type of opening $90 \%$ wind flow. $\mathrm{ACH}>6$ with air velocity $0,2 \mathrm{~m} / \mathrm{s}$ with a user capacity of $50 \%$.

(4) Rooms with an opening area of $5-10 \%$ with an opening type of $45-90 \%$ wind flow are unhealthy and not comfortable to use during a pandemic and post-pandemic times because of $\mathrm{ACH}<4$ and air velocity $<0.2 \mathrm{~m} / \mathrm{s}$. 


\section{Conclusion}

The Covid 19 pandemic made awareness of the quality of space health is something essential. Viruses can spread quickly through droplets with air intermediaries if space conditions are not good. The performance and design of natural ventilation become a significant factor in determining the quality of the health of the space. Research has shown differences in $\mathrm{ACH}$ value, wind speed and space capacity for certain types and areas of openings. Based on the above research results, there need to be adjustments to the Indonesian National Standard (SNI) related to $\mathrm{ACH}$ and the opening area in the room, especially for schools: classrooms and dormitories, to stay healthy and comfortable. This research has not considered the relationship between the type and extent of openings with natural lighting entering buildings with $\mathrm{ACH}$ corresponding to pandemic times or health standards. There needs to be more research should also consider natural living in space to be more comprehensive.

\section{References}

ASHRAE Standard 62.1-2019 (2019). Ventilation for Acceptable Indoor Air Quality. Retrivied from https://covid19.who. int

Astuti, M. (2021). Analisis Efektifitas Penyelenggaraan Pembelajaran Daring di Sekolah Dasar Pada Masa Pandemi Covid-19. Journal of Integrated Elementary Education, 1(1), 41-49. doi: 10.21580/ jieed.v1i1.7224

Bazant, M.Z., Kodio, O., Cohen, A.E., Khan, K., Gu, Z., \& Bush, J.W.M. (2021). Monitoring carbon dioxide to quantify the risk of indoor airborne transmission of COVID-19. medRxiv. doi: https://doi. org/10.1101/2021.04.04.21254903

Camelia, A. (2011). Sick Building Syndrome and Indoor Air Quality. Jurnal IImu Kesehatan Masyarakat, 2(2), 79-84.

Chan, J. F. W., Yuan, S., Kok, K. H., To, K. K. W., Chu, H., Yang, J., Xing, F., Liu, J., Yip, C. C. Y., Poon, R. W. S., Tsoi, H. W., Lo, S. K. F., Chan, K. H., Poon, V. K. M., Chan, W. M., Ip, J. D., Cai, J. P., Cheng, V. C. C., Chen, H., ... Yuen, K. Y. (2020). A familial cluster of pneumonia associated with the 2019 novel coronavirus indicating person-to-person transmission: a study of a family cluster. The Lancet, 395(10223), 514-523. https://doi.org/10.1016/S01406736(20)30154-9

Dai, H., \& Zhao, B. (2020). Association of the infection probability of COVID-19 with ventilation rates in confined spaces. Building Simulation, 13(6), 1321-1327. https://doi.org/10.1007/s12273-020-07035

Domingo, J. L., Marquès, M., \& Rovira, J. (2020). Influence of airborne transmission of SARS-CoV-2 on COVID-19 pandemic. A review. Environmental Research, 188(June), 17-20. https://doi.org/10.1016/j. envres.2020.109861

Geetha, N.B., \& Velraj, R. (2012). Passive cooling methods for energy efficient buildings with and without thermal energy storage - A review. Energy Education Science and Technology Part A: Energy Science and Research 29 (2): 913-946.

Ghinai, I., McPherson, T. D., Hunter, J. C., Kirking, H. L., Christiansen, D., Joshi, K., Rubin, R., Morales-Estrada, S., Black, S. R., Pacilli, M., Fricchione, M. J., Chugh, R. K., Walblay, K. A., Ahmed, N. S., Stoecker, W. C., Hasan, N. F., Burdsall, D. P., Reese, H. E., Wallace, M., ... Layden, J. E. (2020). First known person-to-person transmission of severe acute respiratory syndrome coronavirus 2 (SARS-CoV-2) in the USA. The Lancet, 395(10230), 1137-1144. https://doi.org/10.1016/S01406736(20)30607-3

Hadei, M., Hopke, P.K., Jonidi, A. and Shahsavani, A. (2020). A Letter about the Airborne Transmission of SARS-CoV-2 Based on the Current Evidence. Aerosol Air Qual. Res. 20:911-914. https://doi. org/10.4209/aaqr.2020.04.0158

Hiyama, K., \& Glicksman, L. (2015). Preliminary design method for naturally ventilated buildings using target air change rate and natural ventilation potential maps in the United States. Energy, 89, 655-666. https:// doi.org/10.1016/j.energy.2015.06.026

Latif, S., Hamzah, B., \& Ihsan, I. (2016). Pengaliran Udara Untuk Kenyamanan Termal Ruang Kelas Dengan Metode Simulasi Computational Fluid Dynamics. Sinektika: Jurnal Arsitektur, 14(2), 209216. https://doi.org/10.23917/sinektika. v14i2.1438

Lechner, N. (2015). Heating, Cooling, and Lighting. New Jersey: John Wiley \& Sons, Inc. 
Lippsmeier, G. (1997). Bangunan Tropis. Jakarta: Erlangga.

Lubis, W. (2020). Analisis Efektivitas Belajar Pada Pembelajaran Jarak Jauh (Pjj) Di Masa Pandemi Covid-19. Jurnal Pendidikan Bahasa Dan Sastra Indonesia, 5(1), 139-140.

Lu, J., Gu, J., Li, K., Xu, C., Su, W., Lai, Z.... Yang, Z. (2020). COVID-19 Outbreak Associated with Air Conditioning in Restaurant, Guangzhou, China, 2020. Emerging Infectious Diseases, 26(7), 1628-1631. https://doi.org/10.3201/ eid2607.200764.

Mahdy, M.A. A. (2020). The Impact of COVID-19 Pandemic on the Academic Performance of Veterinary Medical Students. Frontiers in Veterinary Science, 7(October), 1-8. https://doi.org/10.3389/fvets.2020.594261

Minister of Health of the Republic of Indonesia Number 829 / MENKES / SK / VII / 1999

Nambiar, D. (2020). The impact of online learning during COVID-19: students' and teachers' perspective. International Journal of Indian Psychology, 8(2), 783-793. DIP:18.01.094/20200802, DOI:10.25215/0802.094

Nishiura, H., Kobayashi, T., Miyama, T., Suzuki, A., Jung, S. mok, Hayashi, K., Kinoshita, R., Yang, Y., Yuan, B., Akhmetzhanov, A. R., \& Linton, N. M. (2020). Estimation of the asymptomatic ratio of novel coronavirus infections (COVID-19). International Journal of Infectious Diseases, 94, 154-155. $\quad$ https://doi.org/10.1016/j. ijid.2020.03.020

Park, S., Choi, Y., Song, D., \& Kyung, E. (2020). Natural ventilation strategy and related issues to prevent coronavirus disease 2019 (COVID-19) airborne transmission in a school building. Science of the Total Environment, 789, 1-9.

Rachmatantri, I., Hadiwidodo, M., \& Huboyo, H. S. (2015). Pengaruh Pengguna Ventilasi (AC dan Non-AC) terhadap Keberadaan Mikroorganisme Udara di Ruang Perpustakaan (Studi Kasus:Perpustakaan Teknik Lingkungan dan Perpustakaan Biologi Fakultas MIPA Universitas Diponegoro Semarang). Jurnal Teknik Lingkungan, 4(1), 1-2.

Standar Nasional Indonesia (SNI) 03-6572 year 2001 about Procedures for Designing Ventilation and Air Conditioning Systems in Buildings

Zhai, Z. (2020). Facial mask: A necessity to beat COVID-19. Building and Environment, 175, 106827. https://doi.org/10.1016/j. buildenv.2020.106827 